\title{
Selection of Domestic Production Soybean Varieties With the location of planting against the results of production
}

\author{
Nelly Budiharti ${ }^{1}$, J.R. Heksa Galuh $\mathbf{W}^{2}$, Sony Haryanto ${ }^{3}$ \\ 1, 2,3 Industrial Engineering Department, National Institute of Technology ( ITN ), Malang, \\ Indonesia
}

Emai:nelly@lecturer.itn.ac.id

DOI: 10.26821/IJSRC.9.4.2021.9427

\begin{abstract}
To overcome food security, the government has a National Long Term Plan (RPJN) for 2005- 2025 which concludes that until 2019 Indonesia still has a national soybean deficit of more than 229\%. The objectives of this study were: To carry out domestic production of soybeans in various locations in order to meet needs. This research was conducted by means of experimentation using 5 superior varieties grown in 3 districts in Malang district, East Java province, Indonesia. Processing and data analysis using experimental design, namely random block design with a 95\% confidence level. The results showed that the cause of different production results was not due to the use of different varieties. Domestically produced soybean varieties have their respective profiles. Many factors in the selection of domestically produced soybean varieties include size and color.
\end{abstract}

Keywords: soybean varieties, domestic production of soybeans, production results

\section{INTRODUCTION}

The benefits of soybeans are so great and have many uses, that industry players are interested to develop various industrial sectors made from soybeans. Up to you 2019 (Preliminary Study of the National Medium Nelly Budiharti; J.R. Heksa Galuh W; Sony Haryanto; Ngoc Anh Tran, Volume 9 Issue 4, pp 113-116 April 2021
Term Development Plan / RPJMN, Directorate of Food and Agriculture, 2013: 169), it is estimated that soybean imports amounted to $226 \%$. East Java is the largest soybean producer in Indonesia (ranked 1st), on average $42.93 \%$ of Indonesia's total soybean production. The next largest supplier is Central Java (ranked 2nd), 18\%. West Nusa Tenggara (3rd place), $8.79 \%$ and Aceh and West Java alternately entered in the 4th rank giving each contribution of $6.10 \%$ and $5.62 \%$. There is a very large difference between the supplier of rank 1 and rank 2,3 and ranked 4th especially with suppliers from other provinces throughout Indonesia (National Soybean Production Development 2010-2013, BPS 2013: No.73 / 11 / Th. XVI, November 1, 2013: 8). Jember and Banyuwangi are the largest soybean production in Java Timur (BPS 2013). So it is very necessary to make efforts to plant in other areas. In this case, the researcher planted it in Malang Regency, because Malang had already became the city icon of tempe crepe food craftsmen, but soybean farmers are very small, namely only amounting to $11.67 \mathrm{Kw} /$ ha [1-10]

\section{RESEARCH METHOD}

Research was carried out by experiment 5 superior seeds that were applied in 3 sub- districts in Malang Regency, East Java Province, Indonesia. Data 
processing and analysis using an experimental design, namely Block experimental design with a random model. In Cultivation There are many varieties of soybean produced domestically, so the model used is random, the meaning that the conclusion applies to all varieties of soybean production in other countries not only for these 5 varieties[11-18].

\section{RESULT AND DISCUSSION}

From the experimental results, by planting domestically produced soybeans in accordance with the theory and guidelines of the soybean plant research and development unit, department of agriculture, especially food crops, Jember Regency, East Java Province, Indonesia. Production data of 5 domestically produced soybean varieties are as follows:.

Table 1: Production Results of 5 Domestic Production Soybean Varieties (Tons / ha)

\begin{tabular}{|c|c|c|c|c|c|}
\hline Block(Planting & Vari & & & & \\
\hline & Raja Basa & Mutiara 1 & Dega 1 & Dena 1 & Gro \\
\hline Pakis Haji & 2.05 & 2.4 & 2.78 & & 2.77 \\
\hline Singosari & 2.2 & 2.7 & 2.77 & 2.10 & 2.78 \\
\hline Tumpang & 2.4 & 2.7 & 2.91 & 1.9 & 3.01 \\
\hline Amount & 6.65 & 7.8 & 8.46 & 6.05 & 8.65 \\
\hline Average & 2.22 & 2.6 & 2.82 & 2.02 & 2.88 \\
\hline
\end{tabular}

Hypothesis: Variance $(\sigma 2)=0=$ There is no difference in the use of varieties with vegetables on soybean production
Table 2. Analysis of Variance of 5 Domestic Soybeans

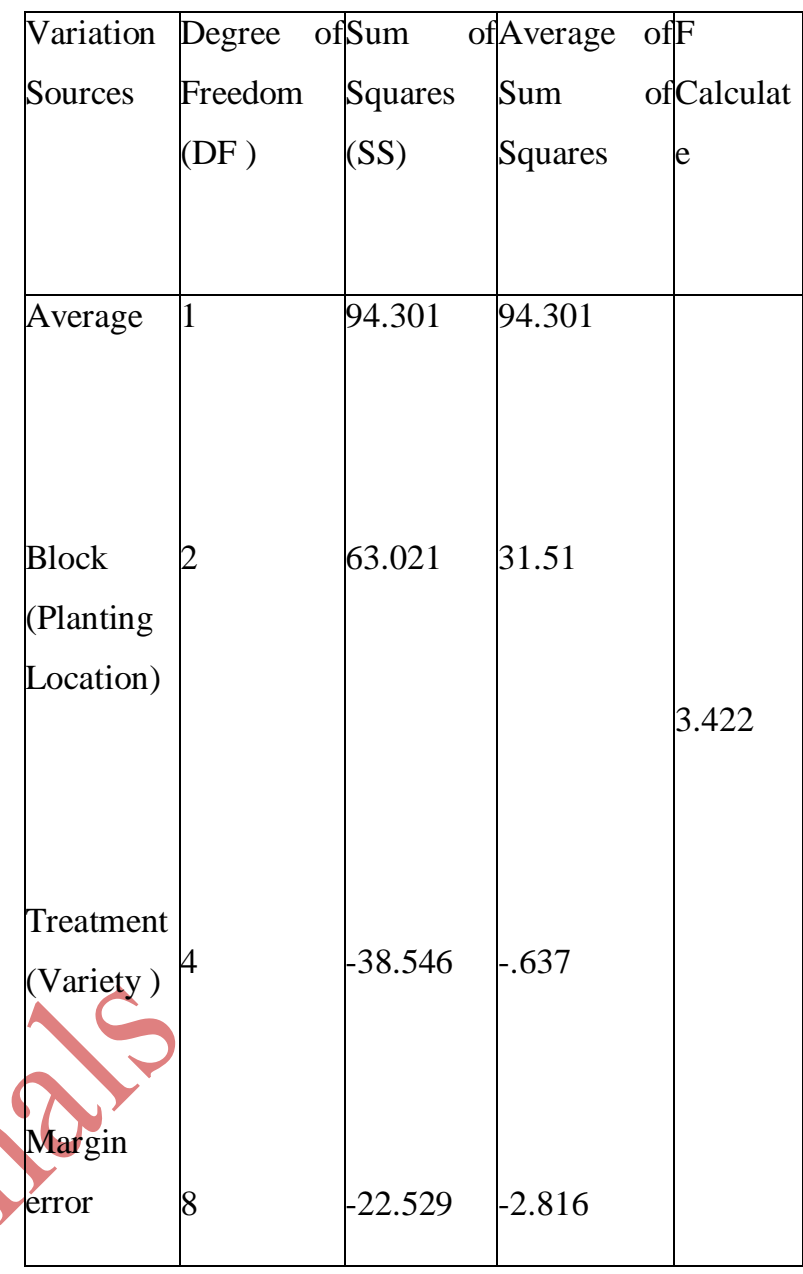

With the confidence level of $95 \%$, the $\mathrm{F}$ value was $0.05(4,8)=3.84 \rightarrow$ with $\mathrm{F}$ calculate $<\mathrm{F}$ table; the hypothesis was confirmed. It meant that there was no difference in the production due to the varieties.

The results showed no differences in the production of various soybean varieties grown alongside / intercropped with vegetables. The differences in the production of various varieties that occur are not due to planting with vegetables / intercropping but indeed each soybean has its own profile, (Source: UPTD Bangsal Sari Jember and Balitkabi Gadang Malang, East Java Province, Indonesia). 
3.1 The profile of the production of each variety is as follows (Source: UPTD Bangsal Sari Jember and Balitkabi

3.2 Gadang Malang, East Java Province, Indonesia): (Ton / Ha)

1.Rajabasa: Potential results 3.9, average $=2.05$

2.Mutiara $\quad:$ Potential results 4.1 , average $=2.4$

3.Dega 1 : Potential results 3.82 , average $=$

2.78

4.Dena1 : Potential results 2.9 , average $=1.7$

5.Grobogan $\quad$ : Potential results 3.4, average $=2.77$ a block again. Also a feature of block design is that each treatment only has 1 observation data, if the observation data is 2 or more, the analysis is said to use a 2-factor design [19]

Soybeans have their respective profiles in addition to the potential for production, namely: diameter size, color, leaf width, tree height, as well as different uses, for example for tempeh, tofu, soy sauce, medicine, beauty, milk, flour, meat Imitation, Salad Oil, M. Fried, White Butter, Margarine, Wetting Agent, Solvent, Emulsifier, Stabilizer, Lubricant, Rerotlen, Ice Cream, Yogurth, Baby food, Soy cheese, etc., [19]

\section{CONCLUSION}

1. Domestic production soybean varieties does not affect the yield obtained

2. Each variety has the potential for production according to the variety profile

3. Variety selection is not based solely on production but there are still many factors including the size and color of soybeans

\section{REFERENCES}

[1] Perlawanan Terhadap Liberalisasi dan Oligopoli Pasar Produk pertanian Tegalan, Balitkabi Purwokerto Jawa Tengah, 2007

[2] Setiawan., Membangun Gerakan Ekonomi
Kolektif Dalam Pertanian Berkelanjutan; Perlawanan Terhadap Liberalisasi dan Oligopoli Pasar Produk pertanian Tegalan, Balitkabi Purwokerto, Jawa Tengah, 2007

[3] Direktorat Jendral Tanaman Pangan, Program dan Kegiatan Pembangunan Pertanian Tanaman Pangan 2015-2019, 2014.

[4] Directorate General of Food Crops, 2014. Programs and Events Agriculture Development (2015-2019).

[5] A.J, Churi, M.R.S. Mlozi, H.Mahoo, S.D.Tumbo and R.Casmir,"A Decision Support System for Enhancing Crop Productivity of Smallholder Farmers in Semi-Arid Agriculture," Journal of Information and Communication Technology Research @2013 ICT Journal, 3(8), ISSN 22234985, 2013

[6] Heriyanto, “ Upaya Percepatan Respon Petani Dałam Peningkatan Kontribusi Varietas Unggul kedelai Trehadap Pendapatan Daerah Jawa Timur," Jurnal Cakrawala, 6(2), Juni 2012: 144128, 2012.

[7] Heriyanto. 2012. Efforts to Accelerate Farmer's Response in Increasing the Contribution of Superior Soybean Varieties to the Revenue of East Java, Journal of Horizon, 6 (2), June 2012: 144128

[8] W. Dogbe, P.M.Etwire, E.Martey, J.C.Etwire, I.I.Y.Baba and A. Siise, Economics of Soybean Production: Evidence from Saboba and Chereponi Districts of Northern Region of Ghana, Journal of Agricultural Science, 5(12), ISSN 1916-9752 EPublished by Canadian Center of Science and Education, 2013.

[9] A. Harsono, "Strategi Pencapaian Swasembada Kedelai melalui Perluasan Areal Tanam di Lahan Kering Masam", IPTEK Tanaman Pangan, 3(2), Bogor, 2008 
[10] G.LHartman, E.D.West and T.K .Herman, “Crops that Feed the World 2. Soybean-Worldwid Production, Use, and Constraints caused by Pathogens and Pests," Food Sec., 3, 5-17, DOI 10.1007/s12571-0100108-x, 2011.

[11] Atman. 2009. Strategi Peningkatan Produksi Kedelai di Indonesia, Jurnal Ilmiah Tambua, 8(1), ISSN 1412-583839.

[12] Atman 2009 (Strategy in Increasing Soybean Production in Indonesia), Tambua Scientific Journal, 8(1), ISSN 1412-583839

[13] F.S.C.Hassan, B. Fakheri and A. Sattari, Review: Breeding for Resistance to Soybean Rust, International Journal of Agriculture and Crop Sciences ( IJACS ), 7(6), 322-328, ISSN 2227670X @2014 IJACS Journal, 2014.

[14] Direktorat Jendral Tanaman Pangan, Road Map Peningkatan produksi Kedelai tahun 2010 - 2014 . Jakarta: Kementan,2010

[15] Directorate General of Food Crops. 2010. Road Map for Soybean Production Increase in 20102014. Jakarta: Ministry of Agriculture.

[16] M. N. Ishaq and B. O. Ehirim," Improving Soybean Productivity Using Biotechnology Approach in Nigeria," World Journal of Agricultural Sciences", 2(2), pp. 013-018. 2014.

[17] Central Bureau of Statistics, Jakarta. 2013

[18] J.A. Jarvie, " A review of soybean rust from a South African Perspective," South African Journal of Science 105, Maret-April, 103, 2009.

[19] T. D. Khanh, T. Q . Anh, B.C.Buu and T. D. Xuan, “ Applying Molecular Breeding to Improve Soybean Rust Resistance in Vietnamese Elite Soybean ," American Journal of Plant Sciences, 4, 1-6, 2013. 